\title{
Variability for Resistance to Phytophthora nicotianae Within a Collection of Nicotiana rustica Accessions
}

J. M. Nifong and J. S. Nicholson, Department of Crop Science, H. D. Shew, Department of Plant Pathology, and R. S. Lewis, Department of Crop Science, North Carolina State University, Raleigh 27695

\begin{abstract}
Nifong, J. M., Nicholson, J. S., Shew, H. D., and Lewis, R. S. 2011. Variability for resistance to Phytophthora nicotianae within a collection of Nicotiana rustica accessions. Plant Dis. 95:1443-1447.

Black shank, caused by Phytophthora nicotianae, is one of the most important diseases affecting tobacco (Nicotiana tabacum) production worldwide. Many current tobacco cultivars possess immunity to race 0 of this pathogen conferred by introgressed dominant genetic factors. Novel alleles conditioning resistance to alternative races are desired. The objective of this research was to evaluate variability for black shank resistance within a collection of $N$. rustica germplasm using both soilborne disease nurseries and controlled race-specific (race 0

ited very high resistance to race 0 , and many displayed levels of race 1 resistance greater than that exhibited by the resistant flue-cured tobacco check, 'K 346'. Materials found to be highly resistant to race 0 and race 1 in growth-chamber experiments also had the best survivability in field disease nurseries. N. rustica accessions TR 6, TR 12, TR 16, TR 21, TR 20, TR 48, TR 54, TR 57, and TR 69 could be sources of novel alleles with large effects on black shank resistance, and could have value for burley and flue-cured tobacco breeding.
\end{abstract} and race 1) inoculations. Nearly all of the 86 accessions studied exhib-
Black shank, caused by the oomycete Phytophthora nicotianae Breda de Haan, is one of the most important diseases affecting commercial tobacco (Nicotiana tabacum L.) production worldwide. Genetic resistance is typically the most attractive way to reduce economic losses from disease in crop plants, and both intraspecific and interspecific sources of resistance have been investigated for cultivated tobacco. Immunity to race 0 of $P$. nicotianae, conferred by genes designated as $P h p$ and $P h l$, has been introgressed into $N$. tabacum from $N$. plumbaginifolia Viv. and $N$. longiflora Cav., respectively $(1,4,13,27)$. These genes provide little or no protection, however, to alternative races of the pathogen that have become increasingly important $(3,24)$. Tobacco breeders have also utilized resistance of the classic quantitative type, where resistance is partial, non-race-specific, and controlled by multiple genes $(5,10,21)$. Based on pedigrees, the cigar tobacco 'Florida 301' (25) is the likely source of the most important polygenes contributing to black shank resistance in current flue-cured and burley tobacco cultivars, although sources with greater levels of resistance have recently been investigated (28). Substantial variability exists among modern tobacco cultivars for level of observed black shank resistance $(11,19)$, presumably resulting from variability in the presence or absence of different components of the Florida 301 polygenic system, or due to their interaction with other genes within the $N$. tabacum genome.

Because complete resistance does not currently exist in tobacco cultivars for black shank races other than race 0 , identification of additional genetic factors that extend the range and level of resistance would be of value. Burk and Heggestad (2) reported in their review that, in addition to $N$. longiflora and $N$. plumbaginifolia, some varieties of $N$. rustica L. possess adequate black shank resistance to be potential interspecific donors of resistance to cultivated tobacco. Litton et al. (18) evaluated two accessions of this species and found one accession to be highly resistant to race 1 but not very resistant to an isolate of race 0 . The second accession exhib-

Corresponding author: J. M. Nifong, E-mail: jessica_nifong@ncsu.edu

Accepted for publication 23 June 2011.

doi:10.1094/PDIS-11-10-0862

(C) 2011 The American Phytopathological Society ited low levels of resistance to both races. Li et al. (17) tested nine accessions of $N$. rustica for resistance to race 1, and reported varying levels of resistance ranging from low to intermediate. Collectively, the studies conducted to date have evaluated only a small fraction of the genetic variation available in this highly polymorphic, allopolyploid species. Due to the known presence of variable levels of black shank resistance within $N$. tabacum germplasm, it seems reasonable that substantial variability might also exist for resistance within the $N$. rustica gene pool.

A collection of 86 diverse accessions of $N$. rustica, which is maintained by the U.S. Nicotiana Germplasm Collection (16), was recently evaluated for a range of morphological characteristics (20). The objective of the research described here was to evaluate this collection of accessions for black shank field resistance and also resistance to specific races (race 0 and race 1 ) of $P$. nicotianae using controlled growth-chamber experiments. If high levels of resistance were identified, it might then be possible to transfer favorable alleles from this species to cultivated tobacco through interspecific hybridization and backcrossing $(6,7,15,29)$. Results from this study could aid researchers in their choice of the most appropriate source materials for breeding efforts, because alleles affecting resistance to race 1 would be of particular value in applied tobacco cultivar development programs.

\section{Materials and Methods}

Field evaluation for black shank resistance. Field experiments were conducted in $P$. nicotianae-infested disease nurseries at the Oxford Tobacco Research Station (Oxford, NC) during the 2005 and 2007 growing seasons. Entries included 86 accessions of $N$. rustica (Table 1; seed obtained from the U.S. Nicotiana Germplasm Collection), 'K 346' (TC 569; high level of quantitative resistance) and 'Hicks' (TC 310; susceptible check) tobacco, and one $N$. rustica $\times N$. tabacum interspecific hybrid (TR 19) of unknown origin and genetic composition maintained by the Collection. All entries were germinated in float trays and subsequently grown, transplanted, and cultivated according to the standard recommendations for flue-cured tobacco $(22,23)$. The experimental design was a randomized complete block design for each year, with four replications during 2005 and three replications during 2007. Plots consisted of single 12-plant rows with 0.56-m withinrow spacing and $1.22-\mathrm{m}$ inter-row spacing. Initial stand counts were recorded approximately 3 weeks after transplanting, and plots 
were evaluated for the number of living plants every other week for a period of 70 days. These data were used to calculate averagedays survival (ADS) for each plot using the formula ADS = $\left(\Sigma_{i} x_{i} y_{i^{*}}\right) / x_{0}$, where $x_{0}$ is the initial stand count, $x_{i}$ is the number of living plants at time $i$, and $y_{i^{*}}$ equals the number of days passed between the stand count at $i$ and the previous stand count $(i-1)$.

Growth-chamber evaluation. An experiment was performed at the North Carolina State University Phytotron to investigate the resistance of this collection of $N$. rustica germplasm to infection with specific races of $P$. nicotianae (race 0 and race 1 ). The experiment had a split-plot design, with four replicates over time and each replicate in a separate growth chamber. The main-plot factor within each replicate was pathogen race ( 0 or 1$)$ and the subplot factor was entry (entries the same as for the field experiment described above, with the addition of the $P h p$-containing germplasm line 'NC 1071' possessing immunity to race 0 and a very low level of resistance to race 1). Experimental units consisted of six plants contained in a six-compartment segment of a '3601' Com-Pack plastic tray insert (T.O. Plastics Inc., Clearwater, MN). Seed were germinated on Metro Mix 200 growing medium (Sun Gro Horticulture, Bellevue, WA) in 9-cm plastic pots under plastic domes at $25^{\circ} \mathrm{C}$ with a photoperiod consisting of $16 \mathrm{~h}$ of light and $8 \mathrm{~h}$ of darkness. Approximately 2 weeks after emergence, seedlings were transplanted into individual cells of the plastic Com-Pack inserts containing a 50:50 mixture of river-bottom sand and Redi-earth Plug and Seedling Mix (Sun Gro Horticulture). Plants were inoculated 7 to 10 days after transplanting by inserting two $P$. nicotianae race 0 - or race 1-infested oat grains into the soil of each cell followed by heavy watering. After inoculation, the temperature during light periods was increased to $30^{\circ} \mathrm{C}$, while the temperature in the dark was maintained at $25^{\circ} \mathrm{C}$. Data were collected for number of surviving plants beginning 7 days post inoculation (dpi) and continuing twice a week until $26 \mathrm{dpi}$. ADS values were calculated for each experimental unit according to the formula provided above.

$P$. nicotianae inoculum. Inoculum for growth-chamber experiments was prepared by growing isolates of either race 0 or race $1 P$.

Table 1. Mean average-days survival (ADS) for entries evaluated in two North Carolina field environments and race-specific growth-chamber experiments

\begin{tabular}{|c|c|c|c|c|c|c|}
\hline \multirow[b]{3}{*}{ Collection identifier } & \multirow[b]{3}{*}{ PI number } & \multirow[b]{3}{*}{ Entry name } & \multirow[b]{3}{*}{ Origin } & \multicolumn{3}{|c|}{ Mean ADS (days) ${ }^{a}$} \\
\hline & & & & \multirow[b]{2}{*}{ Field } & \multicolumn{2}{|c|}{ Growth chamber } \\
\hline & & & & & Race 0 & Race 1 \\
\hline TC 310 & PI 552373 & Nicotiana tabacum 'Hicks'b & United States & $29.8^{\mathrm{k}}$ & $9.8^{\mathrm{kn}}$ & $10.7^{\mathrm{k}}$ \\
\hline TC 364 & PI 552715 & N. tabacum 'NC $1071^{\prime c}$ & United States & & 26.0 & $8.3^{\mathrm{k}}$ \\
\hline TC 569 & PI 549110 & N. tabacum 'K 346'd & United States & 60.9 & 25.7 & 19.8 \\
\hline TR 1 & PI 499162 & 4384-HHS & United States & 61.7 & 25.5 & 19.4 \\
\hline TR 2 & PI 499163 & $4385 \mathrm{~L}-5-6$ & United States & 58.0 & 25.2 & 16.8 \\
\hline TR 3 & PI 499164 & $4386 \mathrm{~L}-5-6$ & United States & 61.6 & 24.8 & 18.5 \\
\hline TR 4 & PI 499165 & 4390 L-5-2-1 & United States & 62.4 & 26.0 & 22.0 \\
\hline TR 5 & PI 499166 & $4398 \mathrm{~L}-5-2-1$ & United States & 66.9 & 25.1 & 22.0 \\
\hline TR 6 & PI 499167 & $4399 \mathrm{~L}-5-2-1$ & United States & $69.0^{\mathrm{K}}$ & 26.0 & $23.6^{\mathrm{K}}$ \\
\hline TR 7 & PI 499168 & 43054 L-5-2-1 & United States & 68.3 & 25.5 & $24.2^{\mathrm{K}}$ \\
\hline TR 8 & PI 499169 & 43101 L-2-1B X L-6-2-1 & United States & 61.4 & 25.5 & 19.5 \\
\hline TR 9 & PI 499170 & 43102-1 L-6-2-1 X L-5-2-1B & United States & 60.8 & 25.5 & 20.3 \\
\hline TR 10 & PI 499171 & 43103-5 L-5-2-1 X L-6-2-1 & United States & 62.2 & 26.0 & 21.2 \\
\hline TR 11 & PI 499172 & 43104-1 L-5-2-1B X L-6-2-1 & United States & 63.2 & 24.9 & 19.3 \\
\hline TR 12 & PI 499173 & $4401 \mathrm{~L}-5-2-1 \mathrm{~B}$ & United States & $69.5^{\mathrm{K}}$ & 26.0 & $23.9^{\mathrm{K}}$ \\
\hline TR 13 & PI 499174 & Brasilia \# 7 & Unknown & 68.0 & 26.0 & 21.7 \\
\hline TR 14 & PI 499175 & Brasilia \# 23 & Unknown & $68.6^{\mathrm{K}}$ & 25.8 & 23.0 \\
\hline TR 15 & PI 34753 & Brasilia Selvaggio & Brazil & 67.9 & 26.0 & 21.2 \\
\hline TR 16 & PI 34752 & Brasilia Leccese & Brazil & $68.6^{\mathrm{K}}$ & 26.0 & $24.8^{\mathrm{K}}$ \\
\hline TR 17 & PI 34754 & Erbasanta & Brazil & 67.2 & 26.0 & 20.5 \\
\hline TR 18 & PI 499176 & 68 Olson & United States & 67.7 & 26.0 & 23.1 \\
\hline TR 19 & PI 499177 & C 39-193 (N. tabacum $\times N$. rustica) & United States & 70.0 & 26.0 & 20.1 \\
\hline TR 20 & PI 499178 & German \# 2 & Unknown & $69.7^{\mathrm{K}}$ & 26.0 & $25.4^{\mathrm{K}}$ \\
\hline TR 21 & PI 499179 & German \# 1 & Unknown & $69.2^{\mathrm{K}}$ & 26.0 & $24.6^{\mathrm{K}}$ \\
\hline TR 22 & PI 499180 & Mahorka \# 1 AC 18/7 & Russia & 64.5 & 26.0 & $24.0^{\mathrm{K}}$ \\
\hline TR 23 & PI 499181 & Mahorka \# 2 Armenia & Russia & 68.0 & 25.2 & 18.6 \\
\hline TR 24 & PI 499182 & Mahorka \# 3 Voronezhskaia & Russia & 64.5 & 26.0 & 20.0 \\
\hline TR 25 & PI 499183 & Mahorka \# 4 Tall Green & Russia & 66.5 & 25.8 & $24.9^{\mathrm{K}}$ \\
\hline TR 26 & PI 499184 & Mahorka \# 5 & Russia & 67.5 & 25.2 & 17.4 \\
\hline TR 27 & PI 499185 & Mahorka \# 6 Yellow \# 109 & Russia & 55.3 & 24.8 & $15.4^{\mathrm{Hk}}$ \\
\hline TR 28 & PI 499186 & Mahorka \# 7 Pekhletzenskaia & Russia & 65.3 & 26.0 & $23.4^{\mathrm{K}}$ \\
\hline TR 29 & PI 499187 & Mahorka \# 8 Prosechenskaia Local & Russia & 66.7 & 23.9 & $15.0^{\mathrm{Hk}}$ \\
\hline TR 30 & PI 499188 & Mahorka \# 9 Stapukhenskaia & Russia & 65.2 & 24.4 & 21.3 \\
\hline TR 31 & PI 499189 & Mahorka \# 10 Sorotooskaia & Russia & $68.5^{\mathrm{K}}$ & 23.5 & 22.4 \\
\hline TR 32 & PI 499190 & Mahorka \# 11 Stalingradskaia & Russia & 66.1 & 24.5 & 16.7 \\
\hline TR 33 & PI 499191 & Mahorka \# 12 Ivisenskaia Local & Russia & 65.0 & 25.1 & $23.5^{\mathrm{K}}$ \\
\hline TR 34 & PI 499192 & Kostoff White Seed \# 14 & Russia & 67.4 & 25.4 & $24.6^{\mathrm{K}}$ \\
\hline TR 35 & PI 499193 & BAK \# 46 & Russia & $68.8^{\mathrm{K}}$ & 24.3 & 19.0 \\
\hline TR 36 & PI 499194 & Koriotes Dark-blue & Russia & 67.5 & 25.4 & 21.2 \\
\hline TR 37 & PI 499195 & Jainkaya Soldata & Russia & 63.0 & 26.0 & $23.3^{\mathrm{K}}$ \\
\hline TR 38 & PI 499196 & Jainkaya Black-blue \# 54 & Russia & 64.1 & 25.2 & $15.2^{\mathrm{Hk}}$ \\
\hline & PI 499197 & Drosgi Black-blue \# 45 & Russia & 67.1 & 25.2 & 18.0 \\
\hline \multirow[t]{2}{*}{ TR 40} & PI 499198 & 14 \# 23057 & Russia & 67.1 & 26.0 & 22.4 \\
\hline & & & & & \multicolumn{2}{|c|}{ (continued on next page) } \\
\hline
\end{tabular}

\footnotetext{
${ }^{a}$ Based on the least significant differences (LSDs) in this table, superscript capital letters indicate positive significant differences between the entry and a check variety, while lowercase letters indicate negative significant differences. Check variety codes: $\mathrm{H} / \mathrm{h}=\mathrm{Hicks}, \mathrm{K} / \mathrm{k}=\mathrm{K} 346, \mathrm{~N} / \mathrm{n}=\mathrm{NC} 1071$.

b Tobacco cultivar chosen as the susceptible check for all experiments.

${ }^{\mathrm{c}}$ Tobacco breeding line chosen as an additional check for Phytophthora nicotianae race-specific experiments due to its differential response (immune to infection by race 0 due to a dominant genomic introgression from $N$. plumbaginifolia known as Php; very susceptible to race 1 infection).

${ }^{\mathrm{d}}$ Tobacco cultivar chosen as the resistant check because it has a high level of quantitative resistance to infection by multiple races of $P$. nicotianae.
} 
nicotianae in sterile petri dishes containing carrot agar $(50 \mathrm{ml}$ of organic carrot juice, $950 \mathrm{ml}$ of distilled water, and $20 \mathrm{~g}$ of agar) in the dark at room temperature. Single layers of autoclaved oat grains were placed on cultures after 3 to 4 days of growth. Oat grains were considered ready for use when they were visibly covered with hyphae, generally 12 to 16 days after they were added to the cultures.

Data analysis. An analysis of variance for ADS was carried out for the field and growth chamber experiments using PROC GLM of SAS (v. 9.1; SAS Institute, Cary, NC). For the field experiment, replication and year were considered random variables while entry was fixed. For the growth-chamber experiment, pathogen race and entry were considered fixed variables while replication was considered a random factor. Entry means were calculated using the LSMEANS procedure of SAS and compared using the least significant difference test as outlined by Gomez and Gomez (12).

\section{Results}

Field study. An analysis of variance of field data from two North Carolina environments with unknown $P$. nicotianae race structures revealed significant differences among entries for ADS $(P<0.0001$; Table 2). The susceptible check cultivar, Hicks, exhibited by far the lowest ADS (29.8 days; Table 1), while the greatest ADS was observed for TR 19 (70.0 days), the $N$. tabacum $\times N$. rustica synthetic hybrid. The $N$. rustica accessions exhibited a relatively narrow range for ADS (54.0 days for TR 50 to 69.8 days for TR 48). Field resistance of all $N$. rustica accessions was excellent, with all of the entries having a significantly greater value for ADS than Hicks $(P<0.0001)$. Nineteen accessions, including the interspecific hybrid TR 19, survived significantly longer than K 346 , the highly resistant flue-cured tobacco check cultivar possessing polygenic resistance, and no $N$. rustica accession exhibited an ADS that was significantly less than that of K $346(P<0.05)$.

Race-specific growth chamber experiments. An analysis of variance on data obtained from inoculation with specific $P$. nicotianae races (race 0 and race 1 ) revealed significant differences among both races $(P<0.01)$ and entries $(P<0.0001)$ for ADS (Table 3). A significant race-entry interaction was also observed $(P$ $<0.0001)$, and race-specific means for ADS in the growth chamber

Table 1. (continued from preceding page)

\begin{tabular}{|c|c|c|c|c|c|c|}
\hline \multirow[b]{3}{*}{ Collection identifier } & \multirow[b]{3}{*}{ PI number } & \multirow[b]{3}{*}{ Entry name } & \multirow[b]{3}{*}{ Origin } & \multicolumn{3}{|c|}{ Mean ADS (days) ${ }^{a}$} \\
\hline & & & & \multirow[b]{2}{*}{ Field } & \multicolumn{2}{|c|}{ Growth chamber } \\
\hline & & & & & Race 0 & Race 1 \\
\hline TR 41 & PI 499199 & Edinburg \# 25 & Russia & 67.0 & 25.8 & 17.4 \\
\hline TR 42 & PI 499200 & Ja. Bot. Gar. \# 30 & France & 66.7 & 25.4 & 16.6 \\
\hline TR 43 & PI 499201 & R. Bot. Gar. \# 29 & Lithuania & $69.1^{\mathrm{K}}$ & 25.7 & 22.7 \\
\hline TR 44 & PI 499202 & Harbin \# 6 & China & 68.2 & 25.4 & 21.1 \\
\hline TR 45 & PI 269933 & $\ldots$ & Pakistan & $68.5^{\mathrm{K}}$ & 25.2 & 20.4 \\
\hline TR 46 & PI 269934 & $\ldots$ & Pakistan & 64.7 & 25.3 & 19.2 \\
\hline TR 47 & PI 269935 & $\ldots$ & Pakistan & 68.2 & 24.8 & 16.4 \\
\hline TR 48 & PI 269936 & $\ldots$ & Pakistan & $69.8^{\mathrm{K}}$ & 24.9 & $23.7^{\mathrm{K}}$ \\
\hline TR 49 & PI 499203 & Chinensis & Turkey & $68.8^{\mathrm{K}}$ & 24.6 & 18.8 \\
\hline TR 50 & PI 499204 & Campanulata & New Zealand & 54.0 & 23.0 & $13.3^{\mathrm{k}}$ \\
\hline TR 51 & PI 499205 & Acutiflora & New Zealand & 63.2 & $21.3^{\mathrm{kn}}$ & $16.3^{\mathrm{Hk}}$ \\
\hline TR 52 & PI 499206 & Fructicora & New Zealand & $68.4^{\mathrm{K}}$ & 25.2 & 22.4 \\
\hline TR 53 & PI 499207 & Acutifolia & New Zealand & 64.3 & 23.6 & 18.8 \\
\hline TR 54 & PI 240355 & Nordugel & New Guinea & $69.3^{\mathrm{K}}$ & 26.0 & $24.0^{\mathrm{K}}$ \\
\hline TR 55 & PI 478886 & GC-1 & India & 68.2 & 25.5 & 17.8 \\
\hline TR 56 & PI 481453 & Hasankeyf & Turkey & 65.0 & 24.0 & $14.9^{\mathrm{Hk}}$ \\
\hline TR 57 & PI 475761 & PNE 241-5 & Pakistan & $68.9^{\mathrm{K}}$ & 24.6 & $24.1^{\mathrm{K}}$ \\
\hline TR 58 & PI 475762 & PNE 362-4 & Pakistan & 67.5 & 23.2 & 17.8 \\
\hline TR 59 & PI 475763 & PNE 369-3 & Pakistan & 66.0 & 25.7 & $23.3^{\mathrm{K}}$ \\
\hline TR 60 & PI 475764 & PNE 373-13 & Pakistan & 64.4 & 25.4 & 20.8 \\
\hline TR 61 & PI 475765 & PNE 407-5 & Pakistan & 66.1 & 25.3 & 22.2 \\
\hline TR 62 & PI 475766 & PNE 412-8 & Pakistan & 68.1 & 25.7 & $22.4^{\mathrm{K}}$ \\
\hline TR 63 & PI 475767 & PNE 417-4 & Pakistan & 66.5 & 22.9 & $24.2^{\mathrm{K}}$ \\
\hline TR 64 & PI 475768 & PNE 418-6 & Pakistan & 67.7 & 25.0 & 22.0 \\
\hline TR 65 & PI 475769 & PNE 420-6 & Pakistan & 64.5 & 26.0 & 20.6 \\
\hline TR 66 & PI 475770 & PNE 427-4 & Pakistan & 62.0 & 26.0 & 21.3 \\
\hline TR 67 & PI 494878 & ZFA 3544 & Zambia & 67.8 & 25.5 & $24.3^{\mathrm{K}}$ \\
\hline TR 68 & PI 494879 & ZFA 3561 & Zambia & 67.7 & 26.0 & 20.3 \\
\hline TR 69 & PI 494880 & ZFA 3564 & Zambia & $69.2^{\mathrm{K}}$ & 24.8 & $23.5^{\mathrm{K}}$ \\
\hline TR 70 & PI 500927 & $\ldots$ & Zambia & 68.3 & 23.2 & $14.3^{\mathrm{Hk}}$ \\
\hline TR 71 & PI 500931 & $\ldots$ & Zambia & $69.3^{\mathrm{K}}$ & 25.7 & 19.2 \\
\hline TR 72 & PI 500932 & $\ldots$ & Zambia & 67.6 & 24.6 & 21.0 \\
\hline TR 73 & PI 500933 & $\ldots$ & Zambia & 68.1 & 25.0 & 20.6 \\
\hline TR 74 & PI 500936 & $\ldots$ & Zambia & $68.4^{\mathrm{K}}$ & 25.5 & 21.1 \\
\hline TR 75 & PI 505664 & ZM/A5133 & Zambia & 68.1 & 25.2 & $23.2^{\mathrm{K}}$ \\
\hline TR 76 & PI 481861 & Maras & Turkey & $69.3^{\mathrm{K}}$ & 26.0 & 22.4 \\
\hline TR 77 & PI 481867 & Karabaglar & Turkey & 62.3 & $21.7^{\mathrm{kn}}$ & $14.7^{\mathrm{Hk}}$ \\
\hline TR 78 & $\ldots$ & Selection from TR36 & United States & 67.9 & 24.8 & $23.3^{\mathrm{K}}$ \\
\hline TR 79 & $\ldots$ & Selection from TR42 & United States & 67.8 & 26.0 & 21.5 \\
\hline TR 80 & $\ldots$ & Selection from TR52 & United States & 66.5 & 26.0 & $23.0^{\mathrm{K}}$ \\
\hline TR 81 & & $\ldots$ & Unknown & 67.9 & 25.2 & $15.5^{\mathrm{Hk}}$ \\
\hline TR 82 & PI 555556 & $\ldots$ & Unknown & 63.1 & 24.3 & 17.3 \\
\hline TW 116 & PI 243561 & N. rustica var. pavonii & Peru & 58.7 & $18.8^{\mathrm{kn}}$ & $15.0^{\mathrm{Hk}}$ \\
\hline TW 117 & PI 555554 & N. rustica var. brasilia & Unknown & 68.3 & 25.1 & 19.9 \\
\hline TW 118 & PI 555555 & N. rustica var. pumila & Unknown & 63.1 & 23.0 & 19.9 \\
\hline TW 119 & PI 555692 & N. rustica & Unknown & 64.3 & 26.0 & 18.1 \\
\hline TW 120 & PI 555693 & N. rustica & Unknown & 64.3 & 24.3 & 16.5 \\
\hline $\operatorname{LSD}(0.05)$ & $\ldots$ & $\ldots$ & $\ldots$ & 7.4 & 3.4 & 3.4 \\
\hline Coefficient of variation (\%) & $\ldots$ & $\ldots$ & $\ldots$ & 11.4 & 11.0 & 11.0 \\
\hline
\end{tabular}


are presented in Table 1 . Hicks was the most race 0 -susceptible entry in the experiment (9.8 days ADS), whereas almost all $N$. rustica accessions exhibited little to no infection. Only three accessions (TR 51, TR 77, and TW 116) exhibited a level of race 0 survival significantly lower than that for NC 1071, a tobacco breeding line immune to race 0 . Excluding these three entries, the range of $N$. rustica race 0 ADS values was 22.9 to 26.0 days, with a mean of 25.2 days.

A much greater range for ADS values (13.3 to 25.4 days; Table 1) was observed among $N$. rustica accessions after inoculation with race 1 of $P$. nicotianae. In total, 32 accessions had ADS values that were significantly different from those of the resistant check cultivar. Of the 10 entries that had significantly lower ADS values than K 346 (19.8 days; $P<0.05$ ), only TR 50 was not significantly different from the susceptible control, Hicks (10.7 days; $P<0.05)$, although TR 50 still survived longer than NC 1071 (8.3 days; $P<$ 0.05 ) in the presence of race 1 . Twenty-two $N$. rustica accessions exhibited high levels of resistance to race 1 , with ADS values significantly greater $(P<0.05)$ than that observed for $\mathrm{K} 346$. Pearson correlation coefficients describing the relationships between ADS in the field and following race 0 and race 1 inoculations were 0.75 $(P<0.0001)$ and $0.54(P<0.0001)$, respectively.

\section{Discussion}

$N$. rustica was previously reported to exhibit moderate to high levels of resistance to one or more races of $P$. nicotianae $(17,18)$, although results have been variable. In order to better understand the scope of black shank resistance in this species, we investigated the largest and most diverse group of $N$. rustica accessions studied to date. Nearly all of the accessions evaluated exhibited very high resistance to race 0 of $P$. nicotianae, with a large proportion that could be rated as immune. By testing such a large collection, our study was also able to reveal more than $20 \mathrm{~N}$. rustica accessions that had significantly higher levels of resistance to race 1 than the resistant flue-cured tobacco check, $\mathrm{K} 346$. This information is valuable to tobacco breeders, because resistance to race 1 of the black shank pathogen is scarce not only in N. tabacum but also within the genus as a whole $(17,18)$. Specifically, the $N$. rustica accessions designated TR 6, TR 12, TR 16, TR 21, TR 20, TR 48, TR 54, TR 57, and TR 69 would be the best sources of novel alleles with large effects on black shank resistance, and could have value for burley and flue-cured tobacco breeding.

When grown in $P$. nicotianae-infested fields and cultivated using standard practices for commercial tobacco, the majority of $N$. rustica accessions evaluated had excellent field resistance, a quality that was also noted by Tisdale and Kelley (26). In race-specific tests, $N$. rustica accessions exhibited very high levels of resistance to the most common race of $P$. nicotianae, race 0 , with only a sin- gle accession (TW 116) having an intermediate level of resistance. These results are at odds with the observations of Litton et al. (18), who, using an index from 0 (no symptoms; immune) to 5 (all plants dead), reported a race 0 disease index for one $N$. rustica accession as 4.5 and rated PI 555554 (TW 117; 48-G) as 4. In the current study, the latter accession had a race 0 ADS value of 25.0 days, which translates into $87 \%$ healthy plants after 26 days of exposure to the pathogen. When this same accession was challenged with race 1, Litton et al. (18) reported a disease index of 3, which is more in line with our results (19.9-day ADS; 64\% healthy plants).

When challenged specifically with race 1 of $P$. nicotianae, the $N$. rustica accessions responded with intermediate to high levels of resistance. These results are generally congruent with those of Litton et al. (18), who reported one highly resistant accession (disease index of 1), as well as intermediate resistance for TW 117 (see above). However, after evaluating a group of nine accessions of $N$. rustica, $\mathrm{Li}$ et al. (17) documented a range in percentage of healthy plants after inoculation with race 1 of 0 to $32 \%$ (very low resistance). For the three accessions that were also included in our study (PI 499162, PI 499163, and PI 499174), Li et al. (17) reported 0,18 , and $24 \%$ healthy plants, respectively, while observations from our study were 38,25 , and $52 \%$. The discrepancies between our results and those of Litton et al. (18) and Li et al. (17) are most likely due to differences in experimental procedures, because both of these groups employed a small-plant technique. Plants in the current study were older, with more established root systems, and were not subjected to intraspecific competition for resources.

Although our study was not intended to address the inheritance or mechanism of this source of resistance to black shank, it seems possible that $N$. rustica may carry a dominant resistance factor conferring immunity to race 0 of $P$. nicotianae, similar to $P h p$ or $P h l$, due to the overwhelming lack of symptom development in most accessions of $N$. rustica during both field and race-specific trials. From a practical breeding point of view, race 0 -specific resistance genes of $N$. rustica origin probably have limited commercial value because immunity to race 0 has already been introgressed into $N$. tabacum from the species mentioned previously. Alternatively, considering that some accessions also have high levels of resistance to race 1, a multigenic system conferring very high levels of quantitative resistance may be present. More studies need to be conducted to resolve this issue. Interestingly, accessions of $N$. longiflora immune to race 0 have also been shown to possess excellent resistance to race 1 (18), but either the source of this resistance is controlled by a different genetic locus or the $P h l$ introgression cannot overcome susceptibility factors present within the $N$. tabacum genome.

Table 2. Analysis of variance for black shank resistance, as measured by average-days survival, for 86 Nicotiana rustica accessions and associated checks grown in two North Carolina field environments

\begin{tabular}{lrcccc}
\hline Source & df & Sum of squares & Mean squares & Computed $\boldsymbol{F}$ & $\boldsymbol{P}$ value \\
\hline Year & 1 & $1,134.2$ & $1,134.2$ & 20.28 & 0.0064 \\
Rep (year) & 5 & 279.7 & 55.9 & 3.63 & 0.0031 \\
Entry & 88 & $17,435.3$ & 198.1 & 3.59 & $<.0001$ \\
Entry $\times$ year & 88 & $4,853.2$ & 55.2 & 3.58 & $<.0001$ \\
Pooled error & 440 & $6,771.2$ & 15.4 & $\ldots$ & $\ldots$ \\
\hline
\end{tabular}

Table 3. Analysis of variance for average-days survival for 86 Nicotiana rustica accessions and associated checks after inoculation in a growth chamber with specific races (0 or 1$)$ of Phytophthora nicotianae

\begin{tabular}{lrcccc}
\hline Source & df & Sum of squares & Mean squares & Computed $\boldsymbol{P}$ value \\
\hline Replication & 3 & 920.0 & 306.7 & 5.48 & 0.0980 \\
Race & 1 & $4,011.5$ & $4,011.5$ & 71.68 & $\ldots .0035$ \\
Error (a) & 3 & 167.9 & 56.0 & $\ldots$ & $\ldots$ \\
Entry & 89 & $3,952.5$ & 44.4 & 7.28 & $<.0001$ \\
Race $\times$ entry & 89 & $1,586.0$ & 6.9 & $\ldots .0001$ \\
Error (b) & 534 & $3,256.7$ & 6.1 & $\ldots$ & $\ldots$ \\
\hline
\end{tabular}


Although neither the amphidiploid species $N$. rustica nor its likely diploid progenitors (N. undulata, and N. paniculata or $N$. knightiana; 8,9), are considered to be close relatives of $N$. tabacum or its diploid precursors (14), it is possible to transfer genetic material from $N$. rustica to cultivated tobacco. For example, Woodend and Mudzengerere (29) introgressed a gene controlling resistance to the angular leaf spot pathogen (Pseudomonas syringae pv. tabaci) from $N$. rustica into cultivated tobacco. Additionally, Chaplin (6) conducted breeding work to transfer an increased genetic capacity to accumulate alkaloids from this species to commercial tobacco, and Legg and Mann (15) demonstrated the effect of introgression of $N$. rustica chromatin on agronomic characteristics of cultivated tobacco after three rounds of backcrossing to $N$. tabacum. Because of the considerable degree of taxonomic divergence between N. rustica and N. tabacum, opportunities for genetic exchanges between $N$. rustica and recipient $N$. tabacum chromosomes are reduced. Therefore, the likelihood of transferring all components of a multigenic resistance system using interspecific hybridization followed by backcrossing is probably low, especially without adversely affecting yield and quality. It may be possible, however, to transfer a few alleles controlling a large proportion of the quantitative resistance to Phytophthora nicotianae race 1 infection from $N$. rustica into $N$. tabacum.

\section{Acknowledgments}

We thank the North Carolina Tobacco Foundation for partial financial support of this research.

\section{Literature Cited}

1. Apple, J. L. 1962. Transfer of resistance to black shank (Phytophthora parasitica var. nicotianae) from Nicotiana plumbaginifolia to N. tabacum. (Abstr.) Phytopathology 52:1.

2. Burk, L. G., and Heggestad, H. E. 1966. The genus Nicotiana: a source of resistance to diseases of cultivated tobacco. Econ. Bot. 20:76-88.

3. Carlson, S. R., Wolff, M. F., Shew, H. D., and Wernsman, E. A. 1997. Inheritance of resistance to race 0 of Phytophthora parasitica var. nicotianae from the flue-cured tobacco cultivar Coker 371-Gold. Plant Dis. 81:12691274.

4. Chaplin, J. F. 1962. Transfer of black shank resistance from Nicotiana plumbaginifolia to flue-cured N. tabacum. Tob. Sci. 6:184-189.

5. Chaplin, J. F. 1966. Comparison of tobacco black shank (Phytophthora parasitica var. nicotianae) resistance from four sources. Tob. Sci. 10:55-58.

6. Chaplin, J. F. 1987. Die Züchtung von Tabak im Hinblick auf verschieden hohe Alkaloidgehalte. Beitr. Tabakforsch. Int. 14:1-9.

7. Chaplin, J. F., and Spurr, H. W. 1982. Altering condensate levels in tobacco smoke by genetic techniques. Beitr. Tabakforsch. Int. 11:151-160.

8. Chase, M. W., Knapp, S., Cox, A. V., Clarkson, J. J., Butsko, Y., Joseph, J., Savolainen, V., and Parokonny, A. S. 2003. Molecular systematic, GISH and the origin of hybrid taxa in Nicotiana (Solanaceae) Ann. Bot. 92:107-127.

9. Clarkson, J. J., Knapp, S., Garcia, V. F., Olmstead, R. G., Leitch, A. R., and Chase, M. W. 2004. Phylogenetic relationships in Nicotiana (Solanaceae) inferred from multiple plastid DNA regions. Mol. Phylogenet. Evol. 33:75-90.

10. Crews, J. W., Wills, W. H., and Laprade, J. L. 1964. Black shank disease reactions of six flue-cured tobacco varieties and the $F_{1}$ hybrids among them. Tob. Sci. 8:128-132.

11. Csinos, A. S., Fortnum, B. A., Powell, N. T., Reilly, J. J., and Shew, H. D. 1984. Resistance to tobacco cultivars and candidate cultivars to Phytophthora parasitica var. nicotianae. Tob. Sci. 28:153-155.

12. Gomez, K. A., and Gomez, A. A. 1984. Statistical Procedures for Agricultural Research, 2nd ed. John Wiley and Sons, New York.

13. Johnson, E. S., Wolff, M. F., Wernsman, E. A., Atchley, W. R., and Shew, H. D. 2002. Origin of the black shank resistance gene, $P h$, in tobacco cultivar Coker 371-Gold. Plant Dis. 86:1080-1084.

14. Knapp, S., Chase, M. W., and Clarkson, J. J. 2004. Nomenclatural changes and a new sectional classification in Nicotiana (Solanaceae). Taxon 53:7382.

15. Legg, P. D., and Mann, T. J. 1961. A study of introgression of N. rustica germplasm into flue-cured varieties of $N$. tabacum. Tob. Sci. 5:136-139.

16. Lewis, R. S., and Nicholson, J. S. 2007. Aspects of the evolution of Nicotiana tabacum L. and the status of the United States Nicotiana Germplasm Collection. Genet. Resour. Crop Evol. 54:727-740.

17. Li, B.-C., Bass, W. T., and Cornelius, P. L. 2006. Resistance to tobacco black shank in Nicotiana species. Crop Sci. 46:544-560.

18. Litton, C. C., Collins, G. B., and Legg, P. D. 1970. Reaction of Nicotiana tabacum and other Nicotiana species to race 0 and 1 of Phytophthora parasitica var. nicotianae. Tob. Sci. 14:128-130.

19. Mila, A., and Radcliff, J. 2009. Managing diseases. Pages 140-174 in: 2009 Flue-Cured Tobacco Guide. North Carolina Cooperative Extension Service.

20. Nifong, J. M. 2008. Assessment of the diversity and disease resistance properties within a collection of Nicotiana rustica. M.S. thesis, North Carolina State University, Raleigh. http://www.lib.ncsu.edu/resolver/1840.16/ 2541.

21. Smith, T. E., and Clayton, E. E. 1948. Resistance to bacterial wilt and black shank in flue-cured tobacco. Phytopathology 38:227-229.

22. Smith, W. D., Fisher, L. R., and Spears, J. F. 2006. Transplant production in the float tray system. Pages 50-69 in: 2006 Flue-Cured Tobacco Information. North Carolina Cooperative Extension Service.

23. Smith, W. D., and Wood, S. 2006. Nutrient management. Pages 70-97 in: 2006 Flue-Cured Tobacco Information. North Carolina Cooperative Extension Service.

24. Sullivan, M. J., Melton, T. A., and Shew, H. D. 2005. Managing the race structure of Phytophthora parasitica var. nicotianae with cultivar rotation. Plant Dis. 89:1285-1294.

25. Tisdale, W. B. 1931. Development of strains of cigar wrapper tobacco resistant to black shank (Phytophthora nicotianae Breda de Haan). Fla. Univ Agric. Exp. Stn. Bull. 226:1-45.

26. Tisdale, W. B, and Kelley, J. G. 1926. A Phytophthora disease of tobacco. Univ. Fla. Agric. Exp. Stn. Bull. 179:1-218.

27. Valleau, W. D., Stokes, G. W., and Johnson, E. M. 1960. Nine years experience with the Nicotiana longiflora factor for resistance to Phytophthora parasitica var. nicotianae in the control of black shank. Tob. Sci. 4:92-94.

28. Vontimitta, V., and Lewis, R. S. Mapping of quantitative trait loci affecting resistance to Phytophthora nicotianae in tobacco (Nicotiana tabacum L.) line Beinhart-1000. Mol. Breed. In press.

29. Woodend, J. J., and Mudzengerere, E. 1992. Inheritance of resistance to wildfire and angular leaf spot derived from Nicotiana rustica var. Brasilea. Euphytica 64:149-156. 